\title{
TRANSLATED IDENTITIES: \\ 'PAKEHA' AS SUBJECTS OF THE TREATY OF WAITANGI
}

Michael Goldsmith

\begin{abstract}
The politics of translation is clearly a perennial focus of debate in New Zealand, as shown by thematic links between the New Zealand social anthropology conferences at Waikato in 1990 and Auckland in 2004. Of the many issues of translation swirling around ongoing attempts to interpret the Treaty of Waitangi, a surprisingly neglected one concerns the identities of the people on behalf of whom the Crown signed the Treaty. The term 'Pakeha' appears only once in the Treaty, the question of whom it refers to is by no means straightforward, and it would be unwise to presume that it had the same range of meanings in 1840 as it does in present-day biculturalism. This point is demonstrated by a re-reading of historical material concerning the parties present at or implicated in the signing of the Treaty, including the so-called Pakeha Maori.
\end{abstract}

It is fitting that the 2004 ASAA/NZ conference organizers in Auckland echoed the theme of the 1990 conference at Waikato, whose convening committee members were conscious of the need to mark the 150th anniversary of the Treaty of Waitangi. The Waikato gathering spawned a volume of essays called Other Sites (Goldsmith and Barber 1992), which sold in the millions or at least 50 copies, whichever is the smaller number. The theme for that sesquicentennial conference was 'Social Anthropology and the Politics of Interpretation', which became the subtitle of our publication. Auckland's thematic subtitle, 'The Cultural Politics of Interpretation' is strikingly similar. Not that I or anyone else engaged in the earlier project has the audacity to claim intellectual property rights. In a short piece for the Association newsletter in the lead-up to the 1990 conference, I had already acknowledged that the phrase 'politics of interpretation' was not original and noted the prior publication of a book of essays from Critical Inquiry published under that title (Mitchell 1983). 
My opinion piece also referred directly to the Treaty of Waitangi, a subject once again rendered topical by the main title of the 2004 event ('Translations, Treaties and Testimonies'). Here is what I wrote in 1989:

Can anyone... really crank a new set of meanings out of our overworked founding document? Yet if interpretive approaches (from hermeneutics to semiology and pragmatism) are united in anything, it is in the view that semiosis is potentially endless.

The suggestion that anthropologists might have something new to say on the Treaty, a matter traditionally reserved to politicians, lawyers, historians, and Maaori Studies experts, is therefore quite sensible. Compare the situation of land rights cases in Australia where anthropologists have assumed the role played primarily by historians in this country. There may be several reasons for this difference: the fact that the Treaty itself was a written document that accompanied the 'literate revolution' in Maaori society; the widely perceived 'historical' significance of the signing; and so on. I think that one very important fact has been the tendency, noted by Peter Gibbons [1986], for New Zealanders to treat colonialism as a phase now past. Hence the acts which established the colonial regime were confined to a particular moment in time - the traditional preserve of historians, who can tell us what really happened (and by doing so, insulate us from its effects). If we accept, on the other hand, that colonisation is a continuing process obscured by debates over national identity, then the ways in which such cultural domination occurs in the present calls for a different form of understanding. [...]

Whether anyone coming to Waikato next year is daring enough to give the Treaty its first post-modernist reading in a public forum is one thing. Nevertheless, the task of analysing the contexts from which such cultural documents gain their force is not only clearly anthropological but also one to which a wide range of thinkers may contribute. On this view, an important and almost totally unanalysed sense of the Treaty is that of the absent (but determining?) subject to which so many of our institutions pay coy lip-service in their newly drafted charters (Goldsmith 1989).

As compelling as this short piece was, there are a few small changes I would make now were I to update it. First, I would remove the hyphen from 'postmodernist'. Put that down to youthful gaucherie. Second, I would probably not 
spell Maori with the double 'a' to mark vowel length, a convention championed by Bruce Biggs and imported to Waikato by his former student, Robert Mahuta. Macrons have won that particular orthographic struggle, though theirs is a pyrrhic victory given the difficulty of getting word processors to obey. Third, the Treaty as determining subject can arguably no longer be described as 'absent' (and perhaps it couldn't in 1989 either). References to it and/or to its 'principles' are now insistently present in every New Zealand public institution. In extenuation, I plead that 1989 was only four years after the Waitangi Tribunal had had its terms of reference extended back to 1840, a step which has generated a correspondingly greater stream of legal, historical and political discourse since my sesquicentennial speculations. Nevertheless, recent political events (such as Don Brash's Orewa speech, the so-called Pakeha backlash, Labour's acquiescence in the retreat from 'race-based' policies, proposed time-limits for Treaty settlements, and Winston Peters' claim that no one can actually provide him with a definition of the Treaty principles) suggest that both the presence and the determining force of the Treaty are less secure than they came to seem for a while during the decade after the 1990 conference.

At the risk of mouthing clichés, the Treaty of Waitangi is continually being reinterpreted. The history of the Treaty links past events to present-day concerns and has done so differently in each generation since 1840 . A by-no-means exhaustive list of these generational changes includes (1) what is understood by 'sovereignty' and its analogues, (2) whether the Treaty is an instrument either of colonial domination or of postcolonial reconciliation, and (3) whether it is the foundational document that the ideology of biculturalism assumes. All of these changes can properly be seen as issues in, and outcomes of, the cultural politics of interpretation.

This present paper, however, will concentrate mostly on another area of cultural interpretation, taking the form of a proposition that the Treaty embodies a number of difficulties in the representation of identities. These difficulties are couched both in terms of the groups who are represented as Treaty partners and in terms of the rights, privileges and obligations that the partnership supposedly entails. I argue that the identities of the people who are assumed in some current discourse to be the signatories, and the identities of those they are assumed to have signed on behalf of, are by no means straightforward. I will address this problem with particular reference to the Crown partner and the people for whom the Crown spoke and continues to speak, albeit in ways of speaking that have continually been redefined. 
Among many background issues that interest me, one has to do with the changes and continuities over time in the use of the term 'European'. I have noted elsewhere (Goldsmith 2004) that many present-day authors confine the use of that term to an early phase of New Zealand history, especially to the first few decades of post-contact history. For reasons that I do not have space to go into here, this practice has a specific valence in anti-racist texts such as Wetherell and Potter's book Mapping the Language of Racism (1992) and in primers on Treaty issues, such as Yensen, Hague and McCreanor's Honouring the Treaty (1989). My research so far has shown that this is a reasonably widespread pattern.

But that pattern is mirrored by another usage, which I want to focus on here. This is the assumption that Pakeha became Pakeha in the contemporary meaning of that transition (i.e., moving from being alien 'European' settlers to 'Pakeha' in-dwellers) almost instantly after 6 February 1840, that is, from the moment of the signing of the Treaty of Waitangi (Goldsmith 2005).

I will be arguing in contrast that the birth of the category 'Pakeha' in something like its hegemonic contemporary sense (as a preferred substitute for 'European' or as the most accepted term for 'white' New Zealanders) was the unsettled endpoint of a much longer process than is recognized in most recent literature. The term predated the Treaty by at least a quarter of a century (Salmond 1997) and its meaning or meanings have often been the subject of heated debate in the nearly 200 years since then. To my mind, the different translations put forward from time to time show more about the assumptions of their proponents than they say about the definitions themselves. The politics of interpretation of the term 'Pakeha' stems from its origin as a native word for outsiders, a word that has either been embraced by its referents (an unusual occurrence in colonial or racial discourse, in which generally those who are more powerful or privileged coin their own labels) or rejected by them precisely because of that origin, fueled by a widespread presumption that it cannot have been intended as a compliment.

\section{TRANSLATING THE TREATY}

It is this context that prompted me initially to analyse the terminology by which settlers and Crown were described in English and Maori language versions of the Treaty. Its rendition into Maori from an original English draft was the work of the Church Missionary Society evangelist Henry Williams. As is well known, a number of commentators have seen his involvement as controversial on the grounds of the supposedly interested nature of the vocabulary 
he chose for such important concepts as 'sovereignty' (see Moon 2002: 139-145; Moon and Fenton 2002; Fenton and Moon 2002, 2004; Sorrenson 2005). I put that debate aside for others to resolve - if they can.

My starting point for exegesis is one that surprised me and may surprise others who feel they have a reasonable grasp of the Treaty and its main provisions: it is that the term Pakeha is absent from all three main articles on which Treaty debate has habitually focused. Where the Treaty does mention 'Pakeha' (and it does so only once) is in the Maori version of its preamble, a part of the Treaty that has received comparatively little scrutiny. The term, in other words, is not exactly banished to the margins of the Treaty but it has been relegated to the margins of Treaty discourse.

It is the Maori version of the Treaty that I therefore turn to first. The label 'Pakeha' occurs in the second paragraph of the preamble: 'Na ko te Kuini e hiahia ana wakaritea te Kawanatanga kia kaua ai nga kino e puta mai ki te tangata Maori ki te Pakeha e noho ture kore ana' (Kawharu 1989: 316; Yensen et al. 1989:27).

Even though the Maori is a translation of an English original, that passage has been translated back into English in a number of ways and for a variety of purposes: partly to check the accuracy of Williams' translation and partly because, on one reading of colonial law, the language of those subjected to the colonizing process becomes the yardstick for judging what colonial treaties actually mean.

Kawharu's literal (and widely used) translation is: 'So the Queen desires to establish the government so that no evil will come to the people Maori [and] to the European living law without' (Kawharu 1989:319). Yensen et al's translation is: 'Now the Queen desires that the governorship may be settled to stem the evils that would come from the native people and the British who dwell there in lawlessness' (Yensen et al. 1989a: 27-28).

The important thing is that these are back-translations from the term 'Pakeha', which is itself a translation of a phrase in the temporally (if not juridically) prior English version that puts things somewhat differently: 'Her Majesty therefore being desirous to establish a settled form of Civil Government with a view to avert the evil consequences which must result from the absence of the necessary Laws and Institutions alike to the native population and to Her subjects...' (Kawharu 1989: 316; Yensen et al. 1989a:30). 
Pakeha is obviously a very free translation of 'Her subjects', but then, I would argue, so are 'European' (Kawharu) or even 'British' (Yensen et al.).

Incidentally, there is an even earlier sentence of the Preamble that refers to 'Her Majesty's Subjects' as well, but that was translated as 'tona Iwi Kua', i.e., '[people of] her nation'. Since the term Pakeha is not used until the second mention of 'Her subjects', arguably it was of secondary importance to Williams. But it is the term that has achieved much greater political resonance. (Nevertheless, the notion of British subjects as an $i w i$ is a tempting topic for further analysis.)

It is not my intention to point to an aporia in the text that destabilises the meanings of the characters referred to in the Treaty and so undermines its political validity. The document will survive as one of the most important constitutional underpinnings of New Zealand politics and I fully support its doing so. But I believe the Treaty is, and should be, robust enough to withstand the various readings placed upon it; and I am enough of a poststructuralist to reject all assertions that its meanings are fixed. Any warrant for the Treaty's notion of Pakeha simply being transposable into the concept as understood within recent biculturalist ideology is complicated by a number of factors. For example:

- The very fact that in Treaty translation discourse the term is almost always translated from the Maori is significant. That is, it is felt to belong strictly speaking to Maori cultural discourse. It is almost as though there is an obligation to translate in such circumstances; translation cannot stop short of translating terms that clearly derive from the origin language. But let us not jump then to the conclusion that a translation from the late 20 th or early 21 st century automatically matches one from 1840.

- If the term Pakeha was in common use in 1840 and therefore warranted as a foundational category in and for accounts of that time, why should many people writing now assume that European is the most appropriate term at that early stage of New Zealand history? In part, it turns out, they do so because it was a widely used term, though not the only one by any means. But that does not explain why it is so commonly assumed to be the most appropriate term. As I noted earlier and have analysed elsewhere, the sequence 'European $\rightarrow$ Pakeha', when taken to refer to a sudden and/or total transition from one identity to the other, has been recruited to the service of a Whiggish narrative of progress toward biculturalism (see Goldsmith 2004, 2005). 
- Did the term Pakeha only apply to British people or did it apply to white people of all nationalities, even those who were not signatories to the Treaty and whom the Treaty may have been designed to control and even exclude from New Zealand? In short, is 'British' an appropriate translation or one that retrojects a particular received version of New Zealand history on to the past? Clearly, the official Maori version does imply that 'Pakeha' should be taken as meaning 'British' people (in the form of Her Majesty's subjects), but that, too, may have been an uncertain and ambiguous usage. The fact that the term 'Pakeha' is used, rather than a term like 'tangata Ingarani', is suggestive. Indeed, there is a section of the Maori translation that does use 'tangata Ingarani'. Was there an intention that the Treaty should apply only to Maori and those of British ancestry, or was it intended to apply to all non-Maori?

I'll address these issues by drawing briefly on some texts describing and analysing the signing of the Treaty. Because the historical archive on this subject is so immense, my investigation is still exploratory and can be criticised for being overly dependent on secondary sources. To that I can only reply that my specific focus on the issue of the ethnic or racial labels makes the material more manageable and that many of the secondary sources are primary sources for the attitudes and assumptions I wish to question. One interim conclusion is that people at the time were, by our own standards, remarkably relaxed about which identity terms should apply to themselves and to others.

WHO SIGNED THE TREATY, WHO WAS IT SIGNED FOR, AND WHO WATCHED?

Take William Colenso's Authentic and Genuine History of the Signing of the Treaty of Waitangi, published some fifty years after the event and therefore full of references to the fact that alterations to his original text were only minor and were made at the time at the suggestion of some fellow eye-witnesses (1890:5-9). On the morning of 5 February 1840, he reports, crowds of people began moving towards Waitangi: 'the officers of the man-o'-war, the suite of the Governor, all the members of the Church Mission residing in or near the Bay of Islands, together with different European and American residents and settlers, kept arriving' (1890: 12). Incidentally, he refers to himself earlier as one of the 'Europeans' who did not sign the Treaty as a witness because his pressing [sic] duties as CMs printer and superintendent prevented him from doing so (1890: 7).

But the rest of his account uses predominantly a binary opposition between 'whites' and 'Natives' (1890: 12, 15, 16. 17, 21, 22, 23, 26, 29, 32, 35). As the source of 
our understanding of many of the chiefly speeches delivered in Maori at Waitangi, it is a shame that the book includes only the English versions of those speeches, so that we do not know what terms the rangatira were using to refer to 'British', 'Europeans', etc. Nor is it clear whether the term 'whites' was being used to distinguish a category separate from those of 'European and American residents and settlers' in the passage just quoted. Perhaps, perhaps not. Henry Williams also referred to 'Europeans' when describing his first encounter with Hobson on board HMs Herald when the newly appointed Governor first arrived at the Bay of Islands (Moon 2002: 140).

Paul Moon, the most staunchly revisionist Treaty historian writing today, questions the big central assumption of most Treaty historiography, 'that the purpose of the Treaty was for the British Crown to assert its sovereign rule over Maori'; rather, he argues that 'the evidence suggests that the Treaty was intended by the Colonial Office to allow Crown rule to apply solely to British settlers in the fledgling colony' (2002: 10). This suggests that he is of the view that, in answer to my earlier question, the Treaty was not meant to apply to other white settlers. He goes on in a manner which strengthens that interpretation but there is a crucial slippage in the language towards the end of the passage I am about to quote: 'The barrier to the Crown asserting the rule of law over any of the British subjects living in New Zealand was that the British Government had yet to secure sovereignty over New Zealand - a technical perquisite for any attempts at establishing legal authority. In practice, the effective limits of British sovereignty were conceived to be over European [sic] settlers' (2002: 130). Suddenly, it is the term 'European' that prevails in this and a number of succeeding paragraphs (2002: 131, 137, 138, 139).

We are indebted to Moon for questioning the assumption that Britain as an imperial power was always dominant when conducting treaty negotiations with indigenous and aboriginal peoples (Moon 2002:125). The contingency of power was even truer of the situation in New Zealand where the Maori were politically more centralized and powerful than some of the other peoples British treaty-makers came up against. That political context is important in understanding the wording of the Treaty but even more important is that, for Maori, the relationship to Britain did not presuppose a straightforward opposition between 'Maori' and 'Pakeha' (as much recent discourse assumes). Rather, at Waitangi, Maori were contending with and reacting to several sets of non-Maori 'others'.

It is important to note here that the same individuals may have occupied more than one of these categories at different times. As Fredrik Barth's seminal 
analysis of ethnic groups established over three decades ago (Barth 1969, 1994, 2000), boundaries persist despite the flow of individuals across them, whether simply in the developmental flow of personal life histories or in situational and cyclical response to economic and ecological opportunities. February 6 1840 represents a brief snapshot in the lives of all those who attended. Some of those who occupied one of the following categories at the time of the Treaty signing went on to occupy other spaces in the New Zealand social universe of the nineteenth century.

The first category comprised the British Crown and its official representatives, who formed a distinct coterie around Busby, Hobson, and their official entourage, including military personnel. This category also arguably included the members of the Church Missionary Society, such as Henry Williams, who symbolically aligned themselves with the Crown, as Colenso describes and Moon reinforces.

Also present as a distinct second category were British settlers outside the official and quasi-official party, who not only fell into the category referred to as 'Her subjects' in the official English version of the Treaty, but who actively embraced, or identified with, that dispensation.

In addition, thirdly, there were some non-British settlers, with their own internal differentiations, who would not automatically see themselves as subject to British government but who were like the previous category in that they consciously saw themselves as separate from Maori control.

Fourth, non-British colonial forces, such as the French, were present in the form of the Roman Catholic missionary, Bishop Pompallier and his entourage (Colenso 189o), and the Americans, who turned up in the form of officers and crew of the US Exploring Expedition and an American consul, who was actually an Englishman (Wilkes 1845, Vol, II: 375-376). The Expedition account acidly notes that Hobson issued proclamations, 'extending his authority over all English residents on both islands! [sic] and it was considered by the Englishmen as good as law, though far otherwise by the other foreigners' (Wilkes 1845, Vol. II:376).

Fifth, there was a particular category of people for whom the term 'Pakeha' had a specific resonance. Many of them were undoubtedly of British origin but some were drawn from a range of other nationalities. All had previously seen themselves as living outside imperial control and some would in future continue to do so. The Treaty in its original English version may not have 
distinguished these people from other 'British' subjects referred to earlier but if they in any way saw themselves as Pakeha, or accepted that label, they had already taken on an identity that the historical and anthropological literature on frontier situations indicates has characteristic features, which I am about to sketch.

\section{PAKEHA AS PAKEHA-MAORI AS PAKEHA}

The final category mentioned in the checklist of those implied in or attending the Treaty signing - the Pakeha, who in 1840 accepted or at least did not resist that label - is, I suggest, actually not opposed to Maori in the way that much present-day Treaty discourse tends to assume. Rather, the term refers in many instances to a category of settler encompassed by Maori, whose chiefs had authority over many Pakeha and who absorbed them within their own culture, which of course was the dominant one in New Zealand/Nu Tireni at the time. In that sense, most of the Pakeha, even if they were not exactly 'rogue' whites living outside and escaping from British justice (though some may well have been), were conceptually outside the purview of imperial control because they had placed themselves under a Maori chiefly dispensation for at least some of the time. In effect, the Treaty reclaimed these Pakeha for the Crown. Its purpose, in other words, was as much if not more about exerting authority over those already in New Zealand as in protecting or governing those who were yet to come.

My paper at this point draws on the work of Trevor Bentley (1999, 2004, and forthcoming), though it does so in ways that he might well disagree with. The research in question concerns his overview of Pakeha Maori in New Zealand history (especially 1999). Reading his work against the grain, it is possible to recover a different perspective. In addition to the role in 'inter-cultural mixing' that Bentley promotes as their greatest achievement (1999:9), the Pakeha Maori confirmed ethnic boundaries in early 19th century New Zealand by adopting roles on either side of the divide as circumstances allowed and their desires dictated. Bentley's assertion that 'Pakeha Maori were never really accepted by either culture' (1999: 221) confuses, I think, the nomadism of many such people with their ability to skillfully adapt to either culture as the situation demanded.

Several points confirm the analysis I have suggested. As Bentley concedes (1999: 10), 'Pakeha Maori' (and therefore presumably also the Pakeha?) included Pacific islanders, 'Negroes', and 'Lascars' (a generic term applied to sailors from India and South East Asia). In short, while they may have been predomi- 
nantly 'white' or 'European', they were not exclusively so.

Bentley is at pains to restrict his analytical category of Pakeha Maori to those 'foreigners who became part of the tribe and were treated by Maori as Maori' (1999: 9) but he acknowledges that all 'Europeans living in New Zealand before 1840 were dependent on Maori for protection to some degree and were compelled to adopt some customs if they hoped to survive or remain', being differentiated by 'the extent to which they integrated with and depended upon Maori for their livelihoods' (1999:10). The most dependent were those whom he categorises as the (real) Pakeha Maori - but on the continuum so established the boundaries may have been both different and more fluid at the time.

There were clearly several important criteria by which to distinguish the extent to which these early settlers, traders and whalers were assimilated by Maori society. These criteria included:

- partial or thoroughgoing rejection of aspects of European culture or political conflict, from a mixture of conversion to Maori ritual understandings (1999: 99-100), desertion from the Royal Navy, or distaste for British strategic adventures and wars $(1999: 17,43)$;

- marriage into Maori society and undertaking of all the forms of kinbased reciprocity so entailed;

- willingness to learn Maori language and culture, a quickly acquired competence in which was aided by the youthfulness of many of the individuals concerned;

- and acceptance of the need to be tattooed in order to match the standards of Maori manliness (1999: 19, 79), though Bentley (1999: 181) states that the records show only thirteen Pakeha Maori agreed to undergo full facial tattooing (moko).

Some also may have carved a niche simply by being able to assist chiefs to avoid the worst strictures of tapu by feeding them and cutting hair for them and other members of the group (1999: 60, 104).

Some committed themselves to lengthy stays in Maori society and resurfaced in the European records much later to recount their stories, thereby shaping the resulting Pakeha Maori narrative mainly in their image. Of those who 
committed themselves permanently, a good many do not figure in subsequent written history because like the vast majority of Maori they did not have their stories recorded in that way. A revealing pattern pieced together by Bentley, however, is that the average length of stay of Pakeha Maori among Nga Puhi, the tribe inhabiting the most contacted part of the country, was just three years (1999:19). Some Pakeha Maori left their tribes because they became disenchanted by the pressures of Maori customary law, especially those who discovered that trying to make their fortunes as traders conflicted with sanctions like utu or plunder on the death of a wife (1999:29). Others became bored by the 'tedium of village life..., breaking the monotony of their lives by periodically visiting Sydney or Hobart' (1999:180). Since most had some naval or maritime skills and experience, they were able to negotiate passage out without too much difficulty (1999:31). A few, like John McGregor, found a role as traveling traders (or 'freebooters') on their own ships, facilitating the exchange of food, muskets and general trade goods between South Island Maori and deep-sea whalers (1999: 46).

The memoirs of perhaps the most iconic 'Pakeha Maori', Frederick Edward Maning, illustrate how boundary-crossing narratives intertwine across a lifetime (Maning 1863). Arriving from Tasmania as a 23-year-old in the Hokianga, he may have observed Maori custom and lived under the protection of a chief, Moetara, but 'remained largely European in outlook' (Bentley 1999: 145). Maning repeatedly referred to individuals whom Bentley calls Pakeha Maori simply as 'pakeha' and informs us that that was how he was called by his chief, i.e., as 'my Pakeha' (Bentley 1999:150-152). In Hocken's Early History of New Zealand (1914), readers are urged to read Maning's classic Old New Zealand to learn about 'the Pakeha's mode of life' (not 'the Pakeha-Maori's', note). Similarly, George Taylor (Hori Punehu), who lived among Ngati Porou for some time, was working as a Native Land Court interpreter in Auckland by 1851, where he was referred to by a Maori witness as 'the red-headed, freckled, blue-eyed Pakeha [note, not Pakeha Maori]" (Bentley 1999: 26).

One of the most famous Pakeha Maori, Jacky Marmon, criss-crossed the geographical and cultural barriers repeatedly. He deserted ship as a teenager from Australia in 1817 and worked for the Church Missionary Society for a while before coming under the patronage and protection of the chief Kawhitiwai, who rewarded his trading and mediating skills by building him a house and enabling him to engage in polygamy. The pattern of living a somewhat European-style existence within, but not entirely part of, Maori tribal society was not uncommon (Bentley 1999: 149). Marmon, however, lost his wealth and trade goods on the death of a wife, so returned to Tasmania. Convicted in a 
Sydney court in 1823 , he escaped back to New Zealand in 1824 and resumed his trading activities (1999: 29), eventually becoming a respected tohunga, albeit one who claimed to do so by preying on Maori superstition and who eventually reverted to Christianity (1999: 107).

Other so-called Pakeha Maori clustered together in ways that make it doubtful that they were ever totally under the authority of chiefly rule (1999: 143-145, 154 ). By the 1820 s and 183 os, there were quite large numbers of fugitive Europeans in the Hokianga, whose assimilation into Maori culture was, as Bentley notes, 'generally less comprehensive' than the earlier ships' deserters and escaped convicts. They 'lived typically as individuals among their own hapu, but congregated together for drinking sprees, weddings, funerals and military campaigns' (1999: 45). Henry Williams noted a contingent of these Hokianga Europeans manning their own cutter on a Nga Puhi expedition to Tauranga, conducting themselves as a tribe within the tribe (1999: 89). They appear not to have been the same as a group of 'sawyers' in the same area at the same time who Bentley says were 'rarely Pakeha Maori' but who blend into his classificatory scheme (1999: 89).

Explicitly included among Bentley's Pakeha Maori category are Pakeha or descendants of mixed marriages who fought as kupapa among the pro-Government forces in the New Zealand Wars (1999:95-96). Whether they routinely described themselves as Pakeha Maori is open to question.

As a tailpiece to this historical summary, Bentley's PhD work (forthcoming) is a rich source of examples of late nineteenth-century New Zealanders - people who would now routinely be described as Pakeha by most newspaper editors - signing their letters to the editors of their day as 'Pakeha-Maori', often in heated debates in which their opponents chose the nom de plume of 'Old Settler'. To repeat: I take from this material a conclusion that Bentley himself has not sanctioned, which is that the boundaries between 'Pakeha' and 'Pakeha Maori' were at the very least more blurred than we might now presume. The fact that 'Pakeha Maori' has different connotations in Maori and English also lends weight to my re-reading of the evidence. Maori tends to place adjectives and other qualifiers after nouns, English the reverse. Hence for Maori (and in contexts where their language was hegemonic), the individuals involved were almost certainly a subtype of Pakeha. For English speakers, another reading was possible, that is, Pakeha Maori as a kind of Maori. Where those two (sets of) categories intersected must have presented some interesting problems of definition to people in 1840 , let alone in 2005 . 
On the basis of the evidence I have assembled here, the Pakeha Maori of 1840 and before were not the standard figures of retrospective biculturalist rhetoric. Rather, they were outsiders - mostly men but occasionally women (Bentley 1999, Chapter 9; 2004) - who were accepted and sometimes dragooned into Maori social networks. Many of them, however, went back and forth across the cultural boundary, some no doubt every day. In general, they were 'white' and of European or Euro-American origin, but there are grounds for thinking that was not always the case and that just being non-Maori would have been sufficient to fall into the category. As Brodkin (1999) has shown, 'white' is a category historically open to re-definition anyway.

In one sense, the Pakeha Maori whom Bentley has chronicled were truer to contemporary biculturalism than many of that philosophy's recent exponents. In later manifestations of biculturalism, the 'bi'-prefix appears to indicate equality or parity, but this has always disguised the encompassment of hierarchy (Dumont 1970). In New Zealand, that hierarchy has largely reversed over time. In the late eighteenth and early nineteenth centuries, Maori generally encompassed Pakeha; since then, in many contexts, Pakeha have symbolically encompassed Maori, for example, in the publicly bicultural space of Te Papa/ The Museum of New Zealand (Goldsmith 2003). The changing nature of this hierarchical encompassment can also be seen quite clearly in the case of intermarriage and miscegenation. The conditions under which one category was seen as assimilating into the other have changed over time and so therefore have the resulting logics of racial 'blood' classification.

Such racialisation of the issue frequently arises in New Zealand popular and populist discourse. There is, for example, a folk theory of the relationship between Maori and Pakeha that echoes what I am saying but does so on the 'racial'/biological/genealogical grounds that Pakeha are 'really' Maori by descent. In doing so, it winds up diametrically opposed to my interpretation despite an initial eerie similarity. Hamilton's free local newspapers recently printed some alarmingly imaginative letters on these matters. From the pen of a vociferous pro-White/anti-Maori correspondent and self-proclaimed historian, M. Hill, came this argument responding to an earlier letter from a correspondent called Rakaipaaka:

Maori were not the first to find New Zealand and (therefore) have no aboriginal rights what so ever. 
The word pakeha is defined by the late Dr King to mean a foreigner, and a foreigner is a person who does not belong to a place, in this case New Zealand.

Rakaipaaka lacks the wisdom to note that there are many different European races now living in New Zealand, and not just one called pakeha. However there is another meaning.

Pakeha means a person who is part Maori. When Captain Cook arrived, Maori had no name for themselves, however, they referred to Cook's men as pakepakeha. After the pakepakeha left New Zealand, a number of mixed-blooded children were born and the people called these children pakeha.

There is another way the word was formed and that meaning also correctly means a person who is part Maori (Hill 2005a, emphasis added; 2005b).

Hill's interpretation keeps alive a perennially strange contest over indigeneity, one that revolves around whether or not Maori have claims to historical priority of settlement vis-à-vis Moriori, the Waitaha Nation, or Phoenicians. This interpretation is diametrically opposed to my argument because, rather than focusing on the socio-political nature of the processes by which Pakeha became part of Maori society (or later became Pakeha in the context of biculturalism), it derives this status from a relationship of blood. Incidentally, I suspect Maori would almost certainly have done the opposite of what Hill claims, that is, the children of the unions between sailors and locals were more likely to be claimed as 'Maori' rather than as 'Pakeha'; but that is an issue for another debate. As a rule of thumb, however, my essay suggests that those translators who most dogmatically insist on the validity of their definitions of fluid terminologies from the past are those we should put least store in.

My overall conclusion, then, is that at the time of the Treaty most Pakeha were a kind of 'naturalized native', through their engagement with Maori. Let me be clear - this is 'native' from the somewhat disapproving viewpoint of the colonial power, not the 'white native' status proudly claimed for a nation-building project in the late 2oth century, as in certain writings by the late Michael King $(1985,1999)$. King was born in New Zealand, loved the place, and claimed to find life elsewhere unimaginable - but ironically it was his (always conditional) incorporation into Maori life through his pioneering historical and bio- 
graphical research that best recreated the kind of originary 'native' status I am referring to. In that sense, he was one of the few people to be truly Pakeha.

\section{ACKNOWLEDGEMENTS}

My debt to Trevor Bentley's research will be apparent to any reader. I hope he does not find my use of his material too cavalier. For useful feedback in thinking through some related aspects of this project, I would like to thank participants at seminars at the Universities of Waikato and Auckland in May 2004 that attracted useful critical feedback, in particular from Keith Barber, Cris Shore, Christine Dureau, Mark Busse and Doug Sutton. The present paper represents a spin-off of the earlier seminar and received its first outing at the December 2004 conference of the Association of Social Anthropologists of Aotearoa/New Zealand in Auckland. My thanks to the conference organizers, Cris Shore, Veronica Strang, Julie Park and Christine Dureau. After that initial presentation, Richard Benton provided exceptionally helpful insights into the history of Treaty translation. An anonymous reviewer for siTEs also made suggestions that contributed greatly to shaping a clearer version of the paper.

\section{REFERENCES}

Barth, Fredrik 1969 Introduction. In Fredrik Barth (ed.), Ethnic Groups and Boundaries: The Social Organization of Cultural Difference. Bergen: Universitetsforlaget/London: Allen and Unwin.

- 1994 Enduring and Emerging Issues in the Analysis of Ethnicity. In Hans Vermeulen and Cora Govers (eds), The Anthropology of Ethnicity: Beyond 'Ethnic Groups and Boundaries'. Amsterdam: Het Spinhuis.

2000 Boundaries and Connections. In Anthony P. Cohen (ed.), Signifying Identities: Anthropological Essays on Boundaries and Contested Values. London: Routledge.

Bentley, Trevor 1999 Pakeha Maori: The Extraordinary Story of the Europeans Who Lived as Maori in Early New Zealand. Auckland: Penguin.

2004 Captured by Maori: White Female Captives, Sexism and Racism on the Nineteenth-Century New Zealand Frontier. Auckland: Penguin. 
_ Forthcoming Images of Pakeha Maori: Representations of the Pakeha Maori in Non-Fiction 1799-1999. PhD thesis in History. Hamilton: University of Waikato.

Brodkin, Karen 1999 Studying Whiteness: What's the Point and Where Do We Go From Here? In Belinda McKay (ed.), Unmasking Whiteness: Race Relations and Reconciliation. Nathan, QLD: Queensland Studies Centre, Griffith University.

Colenso, William 1890 The Authentic and Genuine History of the Signing of the Treaty of Waitangi.... Wellington: George Didsbury, Government Printer. (Reprinted 1971.)

Dumont, Louis 1970 Homo Hierarchicus. The Caste System and its Implications. London: Weidenfeld and Nicolson.

Fenton, Sabine and Paul Moon 2002 The Translation of the Treaty of Waitangi: A Case of Disempowerment. In Maria Tymoczko and Edwin Gentzler (eds), Translation and Power. Amherst, MA: University of Massachusetts Press.

2004 Survival by Translation: The Case of Te Tiriti o Waitangi. In Sabine Fenton (ed.), For Better or For Worse: Translation as a Tool for Change in the South Pacific. Manchester: St Jerome Publishing.

Gibbons, Peter 1986 A Note on Writing, Identity, and Colonisation in Aotearoa. Sites 13:32-38.

Goldsmith, Michael 1989 Setting the Conference Theme: 'The Politics of Interpretation'. NZASA Newsletter 1989/2.

2003 'Our Place' in New Zealand Culture: How the Museum of New Zealand Constructs Biculturalism. Ethnologies Comparées (Printemps) 6. http://alor.univ-montp3.fr/cerce/revue.htm.

2004 Being 'European': Mapping the Language of Racialism in New Zealand. Paper presented to the Departments of Anthropology, University of Waikato and University of Auckland.

2005 Being Pakeha Then: The Genealogy of an Ethnic Label in New Zealand Mythistory. Forthcoming in Frédéric Angleviel (ed.), History and Anthropology volume, Proceedings of the Pacific History Association Conference, Nouméa, December 2004. 
Goldsmith, Michael and Keith Barber (eds) 1992 Other Sites: Social Anthropology and the Politics of Interpretation. Palmerston North: Massey University, Department of Social Anthropology.

Hill, M. 2005a Not a Pakeha [letter]. Hamilton Press (31 August): 4.

-2005b European Anger at Exclusion [letter]! Hamilton This Week (22 September): 8 .

Hocken, Thomas M. 1914 The Early History of New Zealand. Wellington: Government Printer.

Kawharu, I. H. (ed.) 1989 Waitangi: Maori and Pakeha Perspectives of the Treaty of Waitangi. Auckland: Oxford University Press.

King, Michael 1985 Being Pakeha: An Encounter with New Zealand and the Maori Renaissance. Auckland: Hodder and Stoughton.

1999 Being Pakeha Now: Reflections and Recollections of a White Native. Auckland: Penguin.

Maning, Frederick Edward ('A Pakeha Maori') 1863 Old New Zealand: A Tale of the Good Old Times. Auckland: Robert J. Creighton \& Alfred Scales.

Mitchell, W. J. T. (ed.) 1983 The Politics of Interpretation. Chicago: University of Chicago Press.

Moon, Paul 2002 Te Ara Ki Te Tiriti: The Path to the Treaty of Waitangi. Auckland: David Ling.

Moon, Paul and Sabine Fenton 2002 Bound into a Fateful Union: Henry Williams' Translation of the Treaty of Waitangi into Maori in February 1840. Journal of the Polynesian Society 111(1): 51-63.

Salmond, Anne 1997 Between Worlds: Early Exchanges Between Maori and Europeans, 1773-1815. Auckland: Viking.

Sorrenson, Keith 2005 Waitangi: Ka Whawhai Tonu Matou (Waitangi: New Zealand's Enduring Struggle). In Patty O’Brien and Bruce Vaughn (eds), Amongst Friends: Australian and New Zealand Voices from America. Dunedin: University of Otago Press. 
Article $\cdot$ Goldsmith

Wetherell, Margaret and Jonathon Potter 1992 Mapping the Language of Racism: Discourse and the Legitimation of Exploitation. New York: Columbia University Press.

Wilkes, Charles 1845 Narrative of the United States Exploring Expedition. During the Years 1838, 1839, 1840, 1841, 1842. 5 vols. Philadelphia: Lea \& Blanchard.

Yensen, Helen, Kevin Hague, Tim McCreanor 1989 Introduction. In Helen Yensen, Kevin Hague and Tim McCreanor (eds), Honouring the Treaty: An Introduction for Pakeha to the Treaty of Waitangi. Auckland: Penguin. 